Matematikai Közlemények

VII. kötet, 2019

doi:10.20312/dim.2019.04

\title{
Forgólézeres szintezőmüszer kalibrálása
}

\author{
Kalmár János, Orbán Aladár, Gribovszki Katalin \\ MTA CSFK GGI \\ kalmar@ggki.hu
}

\begin{abstract}
ÖSSZEFOGLALÓ: A forgólézeres szintezőműszer lézerfényének méréskor mindig vízszintes síkban kell körbeforognia, ettől való eltérése csak korlátok közt (pl. \pm 0.5 $\mathrm{mm} / \mathrm{m}$ ) megengedett. Az irányzási szintezőmüszer helyzeti hibáját a horizontferdeség és a kúphiba okozhatja. A korábbi vizsgálatok során nem tudták elkülöníteni a két szöghiba hatását, de geometriai modellezéssel sikerült kimutatnunk, hogy speciális helyzetü skála-pozíciókkal a két szöghiba a skáláknál detektált magassági hibák alapján elkülönülten meghatározható.
\end{abstract}

\begin{abstract}
During the measurement procedure, the laser beam of the rotary laser level equipment always have to roll over horizontally. The tail swing of the horizontal roll over is limited, and only about $\pm 0.5 \mathrm{~mm} / \mathrm{m}$ allowed. Positional error of the rotary laser level equipment can be caused by horizon-skewness and cone error. Previous studies could not separate the effect of the mentioned angle errors, but our geometric modeling made it possible, that the angle errors can be separately determined by special located foot rules. In order to determine separetely the angle errors, it is necessary to use the height errors detected at this special located foot rules.
\end{abstract}

\section{Bevezetés}

Intézetünk Tárczy-Hornoch Antal mérőcsarnokában geodéziai müszerek kalibrálása folyik, azaz szabatos mérésekkel megállapítják, hogy a vizsgált müszerek pontossága teljesíti-e a gyártó által vállaltakat - ha nem, akkor szükség van a müszer szakszervizben vagy gyártónál történő beszabályozására.

A forgólézeres szintezőmüszer (1. ábra) belső szerkezetét sajnos nem ismerjük. Feltételezhető, hogy a müszerben van egy állótengely, melyet a müszer felállítása után egy elmés szerkezet automatikusan függőlegesre állít. A lézer fényforrás az állótengely belsejében van felszerelve. Az állótengely felső végére derékszögü prizmát helyeznek, amely az állótengely körül forgatható, és amely az eredetileg függőlegesen haladó lézer-fényt 90 fokkal megtörve vízszintes irányba tereli. Forgás közben a prizma által kivetített lézerfény vízszintes síkot tüz ki. 


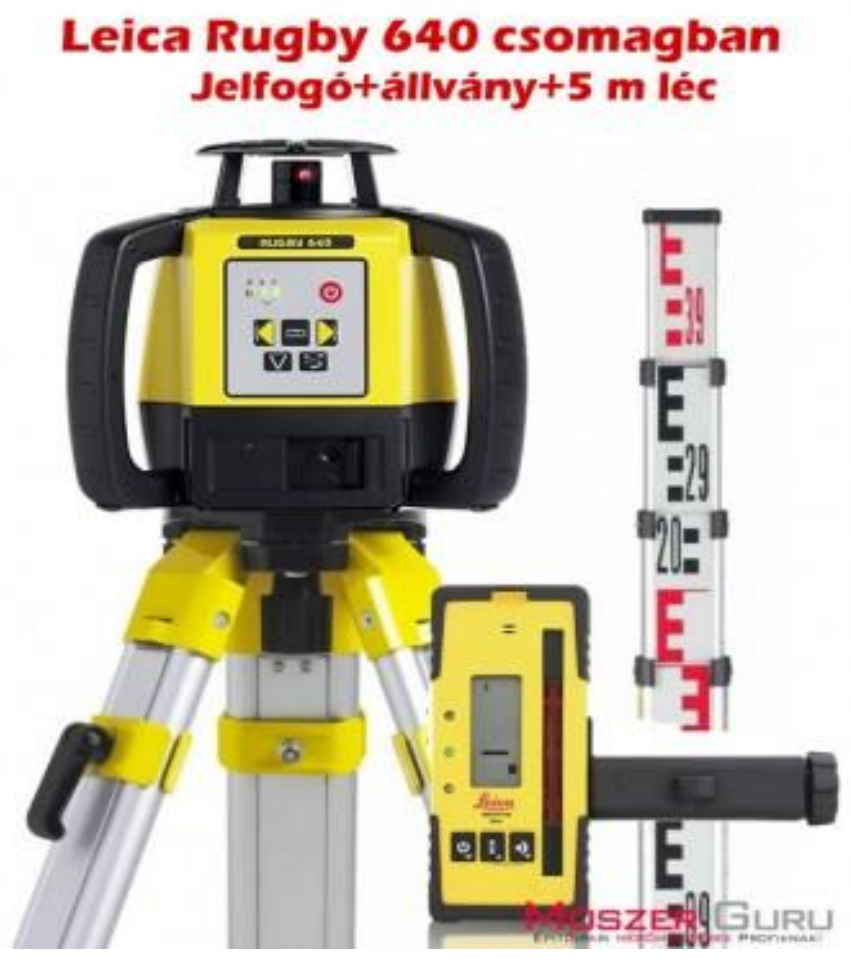

1. ábra. Egy nívós Leica forgólézer szintező szet

\section{A szintezőmúszer kalibrálása}

Vizsgálatainknál a műszert a 30 m hosszú és 4,6m széles laboratóriumunk közepén állítottuk fel (2. ábra), egy vízszintesre szintezett felületen. A terem 4 falára egy-egy függőlegesre állított, mm osztású lécet (skálát) helyeztünk el, amelyeknek kezdőpontját egyforma magasságúra állítottuk.

A legegyszerübb vizsgálatoknál csupán azt figyeljük, hogy a kivetített fény egyforma magasságban pásztázza-e a léceket, (az elkerülhetetlen müszerszabályozási hibák miatt ez még sohasem fordult elö), illetve, hogy mekkora a léceken leolvasott értékek egymástól való eltérése. Ez csupán tájékoztató adatokat szolgáltat az adott távolságokon a müszer pontosságáról.

Részletesebb vizsgálatoknál meghatározhatjuk az adott müszermagasságban vízszintesen haladó fény helyes leolvasási értékét is (Kell érték) a következő módon:

Tekintsük müszermagasságnak a müszer üveg-falán megjelenő kör-alakú fényfolt középpontját. Ez a további müveletek részére úgy jeleníthető meg, hogy a kilépő fény útját vékony papírlappal zárjuk el. Ezen az ernyőn megjelenő kör-alakú fényfolt középpontja a felsőrendű szintezés szabályai szerint a lécre vetíthető. Az így kapott lécpozíció lesz a müszerből kilépő és vízszintesen haladó fény helyes leolvasási, vagy Kell értéke mind a 4 skálán.

A további vizsgálatok alatt a forgó lézer az müszerhibákkal terhelt értékeket vetíti a lécekre. Ezek a Van értékek. A Van - Kell különbség értékei az $s$ skála pozíciójától függő $\delta(s)$ müszerhibák.

Az $\mathrm{r}$ távolság és a $\delta$ hiba ismeretében a müszer hibája $\gamma$ szögértékben is kifejezhető. A hiba ismert $\gamma$ szöge viszont lehetővé teszi, hogy korrekció céljából a gyakorlati munkáknál bármely $r$ léctávolságra kiszámítható legyen a $\delta$ müszerhiba [1]. 
Legyen adott $\mathrm{r}$ és $\delta$ ugyanazon mértékegységben (pl. $\mathrm{mm}$ ), akkora a szögmásodpercben kifejezett $\gamma$ szöghiba kis szögekre felírható $\gamma \approx \rho \cdot \delta / \mathrm{r}$ alakban, ahol $\rho=180 \cdot 60 \cdot 60 / \pi \approx$ $\approx 206265^{\prime \prime}$.

A $\delta$ hiba adott $r$ távolságon ezért felírható a $\delta \approx r \cdot \gamma / \rho$ képlet alapján.

(Ezúton mondunk köszönetet Horváth Attila munkatársunknak Kalibráló Laboratóriumunk kialakításánál nyújtott segítségért, a kalibrálási jegyzőkönyvek és bizonyítványok kiadásánál végzett informatikai munkákért, valamint a mérésekben való részvételéért.)

A forgólézeres szintezőműszer főbb szerkezeti és igazítási hibaforrásai a következők:

Horizontferdeségről akkor beszélünk, ha az állótengely nem függőleges ( $\alpha$ szöghiba). Ebben az esetben a lézerfény forgás közben nem vízszintes, hanem ferde síkot tüz ki, amely egy adott irányban a vízszint alatt, ellenkező irányban a vízszint felett halad.

Kúphiba akkor lép fel, ha a forgó prizma a függőleges fényt nem derékszögben töri meg ( $\beta$ szöghiba). Ekkor a lézerfény állótengely szimmetria-tengelyü tölcsérszerü kúp-palástot pásztáz forgás közben, amely mindig vagy a vízszint felett, vagy az alatt áll.

A kalibráláskor a laboratórium közepén felállított müszerrel körmérést végeztünk a 4 lécen, majd a müszert felemelve a vízszintes lapról 90 fokonként elforgattuk, és megismételtük a körbemérést. A mérési értékeket táblázatba foglaltuk és meghatároztuk a müszerhibák átlagértékét és maximális értékét.

Eddigi méréseink során a két hiba szétválaszthatatlan volt, tehát a laboratóriumban adott $r$ távolságon kapott $\delta$ müszerhiba a horizontferdeség és a kúphiba együttes hatását tükrözte.

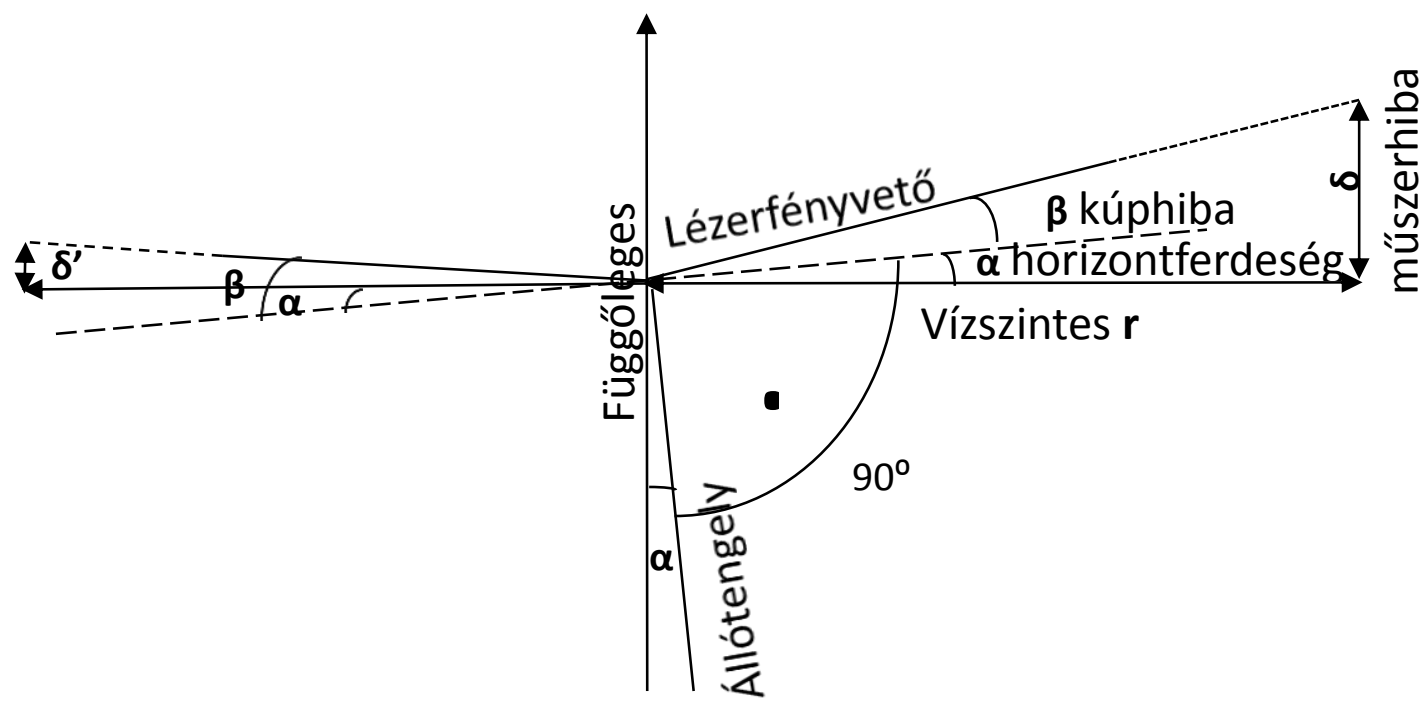

2. ábra. A lézerfényvető tengelyhibái

\section{A kalibrálási eljárás geometriai modellje}

Ha r(s) jelöli a müszer és az s skála távolságát, akkor a $\delta(\mathrm{s}) / \mathrm{r}(\mathrm{s})(\mathrm{mm} / \mathrm{m})$ fajlagos skálahibák meghatározásával hitelesítjük a müszert, és a hiba okát is megnevezhetjük, ha csak egyik típusa fordul elö. A valóságban azonban a horizontferdeségi hiba és a kúphiba egyidejüleg is megjelenhet, egyes skálapozíciókban kiolthatják vagy felerősíthetik egymást, ezért kívánatos lenne hatásuk és nagyságuk elkülönítése és meghatározása még a kalibrálás során, ami a müszer beszabályozását is megkönnyítené.

A 2. ábra jelölései szerint a műszertől a skála $r$ vízszintes távolságra van, a fényvető és a skála definiálta síkban (2. ábra), az állótengely eltérése a függőlegestől $\alpha$ (horizontferdeség), a 
fényvető eltérése pedig az állótengelyre merőlegestől $\beta$ (kúphiba), akkor a mért $\delta$ müszerhiba az alábbi képletekkel számolható ( $\alpha$ és $\beta$ kicsi szöghibák)

$$
\delta=r \cdot \operatorname{tg}(\alpha+\beta) \approx r \cdot(\alpha+\beta)
$$

Látható, hogy a $\delta$ müszerhiba akkor is lehet nulla, ha mindkét szöghiba létezik, de ellenkező nagyságú, ezért egyetlen skálapozícióval (méréssel) a müszer nem minősíthető. (1) miatt $\beta$ felírható az alábbi egyszerủ alakban:

$$
\beta \approx \delta / \mathrm{r}-\alpha
$$

Hasonló összefüggések érvényesek az átellenes skálapozícióban: r’ = r

$$
\begin{gathered}
\delta^{\prime}=\mathrm{r} \cdot \operatorname{tg}(-\alpha+\beta) \approx \mathrm{r} \cdot(-\alpha+\beta) \\
\beta \approx \delta ' / \mathrm{r}+\alpha
\end{gathered}
$$

A $\beta$ kúphiba konstans, ezért (2) $=(4)$ miatt:

$$
\alpha=\left(\delta-\delta^{\prime}\right) / 2 / \mathrm{r}
$$

és (2)-be $\alpha$-t (5) alapján visszahelyettesítve kapjuk:

$$
\beta \approx \delta / \mathrm{r}-\alpha=\left(\delta+\delta^{\prime}\right) / 2 / \mathrm{r}
$$

A (6) képlet alapján látható, hogy a $\beta$ kúphiba már két, átellenes skálapozíción mért müszerhibából meghatározható, de $\alpha$ horizontferdeség (5) nagysága a fényvető irányításától függ, mert az állótengelynek a lézerfény sugara és a fényvető prizmán át húzott függőleges egyenes által kifeszített síkra eső merőleges vetülete fogja definiálni $\alpha$ pillanatnyi értékét.

Az állótengely horizontferdeségét egyetlen $\alpha$ szöggel nem tudjuk jellemezni, szükség van a fényvető irányára is, de mindkettő helyettesíthető az állótengely $\mathbf{a}=\left(\mathrm{x}_{\mathrm{t}}, \mathrm{y}_{\mathrm{t}}, 1\right)$ irányvektorával. Ha az állótengely hibamentes, vagyis függöleges helyzetü, akkor $\mathrm{x}_{\mathrm{t}}=\mathrm{y}_{\mathrm{t}}=0$.

A skálán a Kell pozíció (ahová a lézerfény hibamentes müszer esetén világítana) b irányvektora a müszer fényvető origójú koordinátarendszerében

$$
\mathbf{b}=\left(\mathrm{x}_{\mathrm{s}}, \mathrm{y}_{\mathrm{s}}, 0\right) \text { lesz, és jelölje } \mathrm{r}=\left(\mathrm{x}_{\mathrm{s}}{ }^{2}+\mathrm{y}_{\mathrm{s}}^{2}\right)^{1 / 2}
$$

a müszer és a skála (mérőléc) távolságát. Ismert, hogy

$$
\mathbf{a} \cdot \mathbf{b}=\mathrm{x}_{\mathrm{t}} \cdot \mathrm{x}_{\mathrm{s}}+\mathrm{y}_{\mathrm{t}} \cdot \mathrm{y}_{\mathrm{s}}=|\mathbf{a}| \cdot|\mathbf{b}| \cdot \cos \left(\alpha+90^{\circ}\right)=-|\mathbf{a}| \cdot|\mathbf{b}| \cdot \sin (\alpha),
$$

ahol $|\mathbf{a}|=\left(\mathrm{x}_{\mathrm{t}}^{2}+\mathrm{yt}_{\mathrm{t}}^{2}+1\right)^{1 / 2}$, és $|\mathbf{b}|=\mathrm{r}$, ezért

$$
\begin{gathered}
\sin (\alpha)=-\left(\mathrm{x}_{\mathrm{t}} \cdot \mathrm{x}_{\mathrm{s}}+\mathrm{y}_{\mathrm{t}} \cdot \mathrm{y}_{\mathrm{s}}\right) / \mathrm{r} /|\mathbf{a}| \\
\alpha \approx-\left(\mathrm{x}_{\mathrm{t}} \cdot \mathrm{x}_{\mathrm{s}}+\mathrm{y}_{\mathrm{t}} \cdot \mathrm{y}_{\mathrm{s}}\right) / \mathrm{r} /|\mathbf{a}|
\end{gathered}
$$

Az állótengely irányvektorának, vagyis a horizontferdeség meghatározásához további mérésekre van szükség, mert $(5)=(8)$ csak egy egyenletet ad az állótengely keresett $\left(\mathrm{x}_{\mathrm{t}}, \mathrm{y}_{\mathrm{t}}\right)$ koordinátáira. 
Az új magassági mérések az első két mérés tengelyére merőlegesen történjenek (3. ábra).

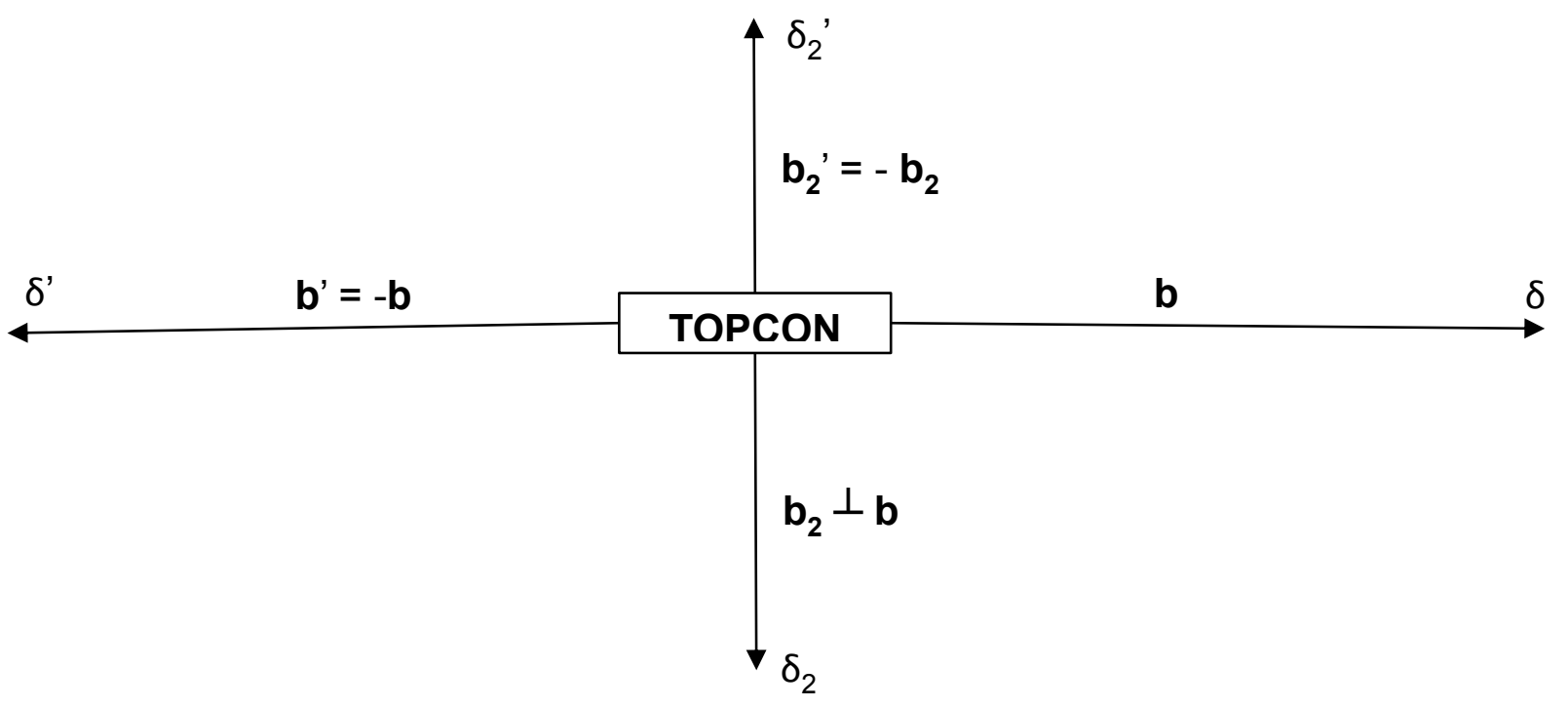

3. ábra. A müszer kalibrálásának skálapozíciói

A meröleges tengelyen a skálák helyvektorai:

$\mathbf{b}_{2}=\left(\mathrm{y}_{\mathrm{s}},-\mathrm{x}_{\mathrm{s}}, 0\right)$ és $\mathbf{b}_{2}{ }^{\prime}=-\mathbf{b}_{2}$ lesznek, amivel aktualizáljuk az (5) és (8) képleteket:

$$
\begin{gathered}
\alpha_{2}=\left(\delta_{2}-\delta_{2}{ }^{\prime}\right) / 2 / \mathrm{r} \\
\alpha_{2} \approx-\left(\mathrm{x}_{\mathrm{t}} \cdot \mathrm{y}_{\mathrm{s}}-\mathrm{y}_{\mathrm{t}} \cdot \mathrm{x}_{\mathrm{s}}\right) / \mathrm{r} /|\mathbf{a}|
\end{gathered}
$$

A állótengely a irányvektorának $\left(\mathrm{x}_{\mathrm{t}}, \mathrm{y}_{\mathrm{t}}\right)$ koordinátáit ezután az $(5)=(8)$ és a $(9)=(10)$ egyenletek megoldásaként kapjuk:

$$
\begin{gathered}
-x_{\mathrm{t}} \cdot \mathrm{x}_{\mathrm{s}}-\mathrm{y}_{\mathrm{t}} \cdot \mathrm{y}_{\mathrm{s}}=|\mathbf{a}| \cdot\left(\delta-\delta^{\prime}\right) / 2 \\
-\mathrm{x}_{\mathrm{t}} \cdot \mathrm{y}_{\mathrm{s}}+\mathrm{y}_{\mathrm{t}} \cdot \mathrm{x}_{\mathrm{s}}=|\mathbf{a}| \cdot\left(\delta_{2}-\delta_{2}{ }^{\prime}\right) / 2
\end{gathered}
$$

A (11) - (12) egyenletek $|\mathrm{a}|$ jelentése miatt egy két-ismeretlenes másodfokú egyenletrendszerhez vezetnek, aminek létezik ugyan algebrai megoldása, de túl bonyolult.

Egyszerüsítsünk annyit a skálák elrendezésén, hogy az első ( $\delta$ müszerhibájú) müszerállás $\mathrm{x}$ tengelyirányú legyen, ezért $\mathrm{x}_{\mathrm{s}}=\mathrm{r}$, és $\mathrm{y}_{\mathrm{s}}=0$, továbbá vezessük be a $\delta_{12}=\delta^{\prime}-\delta$, illetve $\delta_{34}=$ $\delta_{2}-\delta_{2}$ ' jelöléseket;

akkor a (11) - (12) egyenletrendszer a következőképpen néz ki:

$$
\begin{aligned}
& \mathrm{x}_{\mathrm{t}}=|\mathbf{a}| / \mathrm{r} / 2 \cdot \delta_{12} \\
& \mathrm{y}_{\mathrm{t}}=|\mathbf{a}| / \mathrm{r} / 2 \cdot \delta_{34}
\end{aligned}
$$

A (13)-(14) egyenletrendszert egyváltozósra vezethetjük vissza, ha az $\left(\mathrm{x}_{\mathrm{t}}, \mathrm{y}_{\mathrm{t}}\right)$ koordinátákat

$$
\mathrm{x}_{\mathrm{t}}=\mathrm{q} \cdot \delta_{12}, \quad \mathrm{y}_{\mathrm{t}}=\mathrm{q} \cdot \delta_{34}
$$

alakban keressük. Helyettesítsük (15)-öt pl. (13)-ba, akkor kapjuk, hogy

$$
\mathrm{q}= \pm 1 /\left(4 \cdot \mathrm{r}^{2}-\delta_{12}{ }^{2}-\delta_{34^{2}}\right)^{1 / 2}
$$


Mi nem csak az állótengely irányvektorát, hanem annak a függőlegestől való $\alpha_{\max }$ eltérését is keressük, amit az alábbi képlet szolgáltat:

$$
\sin \left(\alpha_{\max }\right)=\left(\mathrm{xt}_{\mathrm{t}}^{2}+\mathrm{y}_{\mathrm{t}}^{2}\right)^{1 / 2} /|\mathbf{a}|
$$

$\left(\mathrm{x}_{\mathrm{t}}, \mathrm{y}_{\mathrm{t}}\right)(15)-(16)$ megoldását behelyettesítve és egyszerüsítve kapjuk:

$$
\sin \left(\alpha_{\max }\right)=\left(\delta_{12}{ }^{2}+\delta_{34}{ }^{2}\right)^{1 / 2} / 2 / \mathrm{r} .
$$

A (18) képletből a szinusz függvényt argumentumával helyettesíthetjük, mert várhatóan kis $\alpha_{\max }$ hibaszögről van szó.

A fényvető $\beta$ kúphibájának (6) képlete úgy interpretálható, hogy két átellenes müszerhiba átlagát osztjuk a skálák $\mathrm{r}$ müszertávolságával. $\mathrm{Az}$ állótengely irányvektorának meghatározásához viszont négy skála-pozícióra volt szükség, ezért a $\delta_{2}, \delta_{2}$ ' átellenes müszerhibák alapján is felírható $\beta$ egy becslése. Végeredményben a négy skálapozíció miatt a müszer $\beta$ kúphibájára két becslésünk lesz, ezeket átlagolva a statisztikailag robusztusabb

$$
\beta=\left(\delta+\delta^{\prime}+\delta_{2}+\delta_{2}{ }^{\prime}\right) / 4 / \mathrm{r}
$$

kúphiba becsléshez jutunk, azaz vesszük a négy müszerhiba átlagát, és elosztjuk azt a müszer és a skála távolságával. Vegyük észre, hogy a (18)-(19) képletek jól interpretálják a szöghibák alapeseteit:

- A müszernek csak horizontferdeségi hibája van. Az átellenes müszerhibák egyformák, de ellentétes elöjelüek: $\delta+\delta^{\prime}=0, \delta_{2}+\delta_{2}{ }^{\prime}=0$, tehát $\beta=0$, vagyis nincs kúphiba.

- A müszernek csak kúphibája van. A müszerhibák egyformák: $\delta=\delta^{\prime}=\delta_{2}=\delta_{2}$, , ezért $\beta=\delta / \mathrm{r}$, de $\delta / \mathrm{r}=\operatorname{tg}(\beta)$, ami kis szögeknél jó közelítő értéke $\beta$-nak. Ezen megfontolás alapján $\beta$ (19) becslését tovább élesíthetjük:

$$
\operatorname{tg}(\beta)=\left(\delta+\delta^{\prime}+\delta_{2}+\delta_{2}{ }^{\prime}\right) / 4 / \mathrm{r}
$$

\section{A szöghibák becslése modellezett műszerhibák alapján}

Különböző a állótengely irányvektorokat, vagyis $\alpha_{\max }$ horizontferdeségeket és $\beta$ kúphibákat modelleztünk. Adott b irányvektorú skálapozícióhoz (7) alapján kiszámítottuk az állótengely vetületének $\alpha$ eltérését a függőlegestől, és az $\mathrm{r}=|\mathbf{b}|$ léctávolság ismeretében (1) alapján kiszámítottuk a $\delta$ müszerhibákat. Megvizsgáltuk, hogy a (15), (16) képletek milyen pontosan

\begin{tabular}{|c|c|c|c|c|c|c|}
\hline modellezett & \multicolumn{2}{|c|}{ a állótengely iránya } & \multirow{2}{*}{$\begin{array}{c}\text { horizont-ferdeségi } \\
\text { hiba }\left(\alpha_{\max }\right)\end{array}$} & \multicolumn{2}{|c|}{ skálapozíciók } & \multirow{2}{*}{$\begin{array}{l}\text { modellezett } \\
\delta \text { müszerhiba }\end{array}$} \\
\hline kúphiba $(\beta)$ & $\mathrm{X}_{\mathrm{t}}$ & $\mathrm{y}_{\mathrm{t}}$ & & $\mathrm{X}_{\mathrm{s}}$ & $\mathrm{y}_{\mathrm{s}}$ & \\
\hline $3^{0}$ & 0,06 & 0,08 & $5,7105931^{0}$ & 3 & 0 & $-0,02213403$ \\
\hline becsült & \multicolumn{2}{|c|}{ a állótengely becsült iránya } & horizont-ferdeségi & -3 & 0 & 0,33770862 \\
\hline kúphiba $(\beta)$ & $\mathrm{X}_{\mathrm{t}}$ & $\mathrm{y}_{\mathrm{t}}$ & becsült hiba $\left(\alpha_{\max }\right)$ & 0 & -3 & 0,39846009 \\
\hline $3,0149449^{0}$ & 0,060276 & 0,080481 & $5,7418185^{0}$ & 0 & 3 & $-0,08200263$ \\
\hline
\end{tabular}
adják vissza az állótengely irányvektorát, illetve a (18), (19) képletek a modellezett szöghibákat. Kiderült, hogy a becslések csak a harmadik értékes jegyben térnek el a modellezett értékektől (1. táblázat).

1. táblázat. A szöghibák becslése a modellezett müszerhibák alapján 
Ezen csekély hiba forrása is megmagyarázható: a képletek levezetésekor a szinusz és tangens szögfüggvényeket argumentumukkal helyettesítettük, ami 0 közelében elfogadott egyszerüsítés. A modellezett szöghibák viszont $3-6$ fokosak voltak, amik már elég távol vannak az origótól ahhoz, hogy becslési hibát okozzanak - a gyakorlatban a megfelelő pontosságú müszerek szöghibái 1 szögperc alatt vannak, vagyis két nagyságrenddel kisebbek.

A levezetett becslő képletek csak a skálák és a müszer $r$ távolságát illetve a $\delta$ müszerhibákat tartalmazzák. Megvizsgáltuk, hogyan változnak a számítási eredmények, ha nem standard skálapozícióból (az első méröléc az x tengelyhez képest $\gamma=70^{\circ}$ szöggel elforgatott pozícióban van) indulunk ki (2. táblázat).

\begin{tabular}{|c|c|c|c|c|c|c|}
\hline modellezett & \multicolumn{2}{|c|}{ a állótengely iránya } & horizont-ferdeségi & \multicolumn{2}{|c|}{ skálapozíciók } & modellezett \\
\hline kúphiba $(\beta)$ & $\mathrm{X}_{\mathrm{t}}$ & $\mathrm{y}_{\mathrm{t}}$ & $\operatorname{hiba}\left(\alpha_{\max }\right)$ & $\mathbf{X}_{\mathrm{S}}$ & $\mathrm{y}_{\mathrm{s}}$ & $\delta$ müszerhiba \\
\hline $3^{0}$ & 0,06 & 0,08 & $5,7105931^{0}$ & 1,026 & 2,819 & $-0,1290985$ \\
\hline becsült & \multicolumn{2}{|c|}{$\mathrm{a}$ állótengely becsült iránya } & horizont-ferdeségi & $-1,026$ & $-2,819$ & 0,4464304 \\
\hline kúphiba $(\beta)$ & $\mathrm{X}_{\mathrm{t}}$ & $\mathrm{y}_{\mathrm{t}}$ & becsült hiba $\left(\alpha_{\max }\right)$ & 2,819 & $-1,026$ & 0,0704527 \\
\hline $3,0149908^{0}$ & 0,096407 & $-0,02911$ & $5,7418185^{0}$ & $-2,819$ & 1,026 & 0,2442570 \\
\hline
\end{tabular}

2. táblázat. A szöghibák becslése nem standard skálapozíciók esetén

Kiderült, hogy a szöghibák (18) és (19) becslése invariáns (nem változik) az elforgatásra (előzetesen ezt vártuk), viszont az a állótengely irányvektorának (15) és (16) alapján becsült $\left(\mathrm{x}_{\mathrm{t}}, \mathrm{y}_{\mathrm{t}}\right)$ koordinátáit az első skálapozícióba forgatott $\mathrm{x}$ tengelyü koordináta-rendszerben kaptuk meg. Mindezekböl következően a valódi $\left(\mathrm{x}_{\mathrm{t}}{ }^{\prime}, \mathrm{y}_{\mathrm{t}}{ }^{\prime}\right)$ koordinátákat úgy számíthatjuk ki, hogy a becsült koordinátákat ugyanolyan forgatásnak vetjük alá, mint amilyen forgatással $\left(\cos (\gamma)=\mathrm{x}_{\mathrm{s}}\right.$ $\left./ \mathrm{r}, \sin (\gamma)=\mathrm{y}_{\mathrm{s}} / \mathrm{r}\right)$ az elsö $\left(\mathrm{x}_{\mathrm{s}}, \mathrm{y}_{\mathrm{s}}\right)$ müszerállást nyertük a standard $(\mathrm{r}, 0)$ pozícióhoz képest:

$$
\mathrm{x}_{\mathrm{t}}{ }^{\prime}=\left(\mathrm{x}_{\mathrm{t}} \cdot \mathrm{x}_{\mathrm{s}}-\mathrm{y}_{\mathrm{t}} \cdot \mathrm{y}_{\mathrm{s}}\right) / \mathrm{r}, \quad \mathrm{yt}^{\prime}=\left(\mathrm{x}_{\mathrm{t}} \cdot \mathrm{y}_{\mathrm{s}}+\mathrm{y}_{\mathrm{t}} \cdot \mathrm{x}_{\mathrm{s}}\right) / \mathrm{r}
$$

\section{Az eljárás tesztelése műszervizsgálattal}

A mérőcsarnokban korábban egy TOPCON forgólézeres szintezőműszer lett kalibrálva, vagyis meg lettek mérve a négy mérőlécen a müszerhibák. A mérés során teljesült az átellenes skálatengelyek merőlegessége, de a vizsgálóhelyiség adottságai miatt a müszertől a skálák eltérő távolságra helyezkedtek el (3. ábra, $|\mathbf{b}|=15 \mathrm{~m},\left|\mathbf{b}_{2}\right|=2,3 \mathrm{~m}$ ). A mért $\delta$ müszerhibákat ezért a háromszög hasonlóság alapján 10 méter müszer-skála távolságra normáltuk, és az így korrigált hibák alapján számítottuk ki a kúphibát és a horizontferdeséget (3. táblázat). A müszerhibákból jól látszott, hogy a müszer pontos, mérési hibája nem haladta meg a $0,5 \mathrm{~mm} / \mathrm{m}$ t, ezért csak kis szöghibákra számítottunk.

Képleteinket alkalmazva az $\alpha_{\max }$ szöghibák átlaga 38 szögmásodperc, a $\beta$ szöghibák átlaga pedig 24 szögmásodperc lett, vagyis a müszernek valóban csak elhanyagolható irányhibája van. Azért beszélhetünk átlagról, mert a müszerrel több mérési sorozatot végeztünk úgy, hogy közben a müszer helyzetét (állótengelyét) változtattuk, azimutját a föirányokba $\left(0^{\circ}, 90^{\circ}, 180^{\circ}\right.$, $270^{\circ}$ ) forgattuk. Az átlagolt eredmények hibáját a szórásukkal jellemezhetjük, és az $\alpha_{\max }$ szöghibák szórása 5 szögmásodperc, a $\beta$ kúphibák szórása pedig 3 szögmásodperc lett, ami a pontos mérések mellett a számított szöghibák (vagyis (18)-(19) képletek) jó becslésére utal. 


\begin{tabular}{|c|c|c|c|c|c|c|c|c|c|c|c|c|c|}
\hline $\begin{array}{l}\text { Müszer } \\
\text { azimut }\end{array}$ & $\begin{array}{c}\text { Skála } \\
\text { pozíció }\end{array}$ & $\begin{array}{c}\text { Hiba } \\
\mathrm{mm}\end{array}$ & $\begin{array}{c}\text { Korrigált } \\
\text { hiba }\end{array}$ & $\begin{array}{l}\text { Skálatáv } \\
\text { méter }\end{array}$ & $\begin{array}{c}\text { Sugár } \\
\mathrm{m}\end{array}$ & $\begin{array}{l}\boldsymbol{\delta}_{12}= \\
\delta^{\prime}-\delta\end{array}$ & $\begin{array}{c}\delta_{34}= \\
\delta_{2}-\delta_{2}^{\prime}\end{array}$ & $\underset{\boldsymbol{\alpha}_{\max }}{\text { radián }}$ & $\begin{array}{c}\boldsymbol{\beta} \\
\text { radián }\end{array}$ & $\begin{array}{c}\boldsymbol{\alpha}_{\max } \\
\text { fok }\end{array}$ & $\begin{array}{c}\boldsymbol{\beta} \\
\text { fok }\end{array}$ & $\begin{array}{c}\boldsymbol{\alpha}_{\max } \\
\text { sec }\end{array}$ & $\underset{\mathrm{sec}}{\boldsymbol{\beta}}$ \\
\hline \multirow[t]{4}{*}{$0^{0}$} & $\delta^{\prime}$ & 1,5 & 1,00 & 15 & 10 & 1,667 & 3,913 & 0,00021 & 0,00011 & 0,0122 & 0,0061 & 44 & 22 \\
\hline & $\delta_{2}^{\prime}$ & 0,0 & 0,00 & 2,3 & & & & & & & & & \\
\hline & $\delta$ & $-1,0$ & $-0,67$ & 15 & & & & & & & & & \\
\hline & $\delta_{2}$ & 0,9 & 3,91 & 2,3 & & & & & & & & & \\
\hline \multirow[t]{4}{*}{$90^{\circ}$} & $\delta^{\prime}$ & 0,8 & 0,53 & 15 & 10 & 1,200 & 3,043 & 0,00016 & 0,00014 & 0,0094 & 0,0079 & 34 & 28 \\
\hline & $\delta_{2}^{\prime}$ & 0,3 & 1,30 & 2,3 & & & & & & & & & \\
\hline & $\delta$ & $-1,0$ & $-0,67$ & 15 & & & & & & & & & \\
\hline & $\delta_{2}$ & 1,0 & 4,35 & 2,3 & & & & & & & & & \\
\hline \multirow[t]{4}{*}{$180^{\circ}$} & $\delta^{\prime}$ & $-0,9$ & $-0,60$ & 15 & 10 & $-1,933$ & $-3,478$ & 0,00020 & 0,00011 & 0,0114 & 0,0060 & 41 & 22 \\
\hline & $\delta_{2}^{\prime}$ & 0,8 & 3,48 & 2,3 & & & & & & & & & \\
\hline & $\delta$ & 2,0 & 1,33 & 15 & & & & & & & & & \\
\hline & $\delta_{2}$ & 0,0 & 0,00 & 2,3 & & & & & & & & & \\
\hline \multirow[t]{4}{*}{$270^{\circ}$} & $\delta^{\prime}$ & $-0,9$ & $-0,60$ & 15 & 10 & $-1,867$ & $-2,609$ & 0,00016 & 0,00013 & 0,0092 & 0,0072 & 33 & 26 \\
\hline & $\delta_{2}^{\prime}$ & 0,8 & 3,48 & 2,3 & & & & & & & & & \\
\hline & $\delta$ & 1,9 & 1,27 & 15 & & & & & & & & & \\
\hline & $\delta_{2}$ & 0,2 & 0,87 & 2,3 & & & & & & & & & \\
\hline & & & & & & & Átlag & 0,00018 & 0,00012 & 0,0105 & 0,0068 & 38 & 24 \\
\hline & & & & & & & Szórás & 0,00003 & 0,00002 & 0,0015 & 0,0009 & 5 & 3 \\
\hline
\end{tabular}

2. táblázat: a TOPCON müszer kalibrálásának eredménye

\section{6. Összefoglaló}

Geometriai modellezéssel sikerült kimutatnunk, hogy speciális helyzetü mérőléc pozíciókkal a forgólézeres szintezőmüszer horizontális ferdesége és kúphibája a léceknél mért magassági hibák alapján elkülönülten meghatározható.

A (11)-(12) két ismeretlenes, másodfokú egyenletrendszer megoldásait feltünően egyszerü (15)-(16) alakban sikerült felírni, a szöghibák pedig a (18)-(19) képletek alapján számíthatók.

Mind a kísérleti számmodellekben (1. és 2. táblázatok), mind a valós mérések (3. táblázat) alapján sikerült az elméleti eredményeket (képleteket) validálni.

\section{Irodalomjegyzék}

[1] [Orbán, A. (2000) Minőségügyi kézikönyv. Forgólézeres szintezőműszerek kalibrálása. Belső használatra. 